Supporting Information

\title{
Synergistic effects of reduced nontronite and organic ligands on $\operatorname{Cr}(\mathrm{VI})$
}

reduction

Xiaolei Liu ${ }^{1,2}$, Hailiang Dong ${ }^{1,2,3^{*}}$, Qiang Zeng ${ }^{2,3}$, Xuewei Yang ${ }^{2,3}$, and Donglei Zhang $^{2}$

\footnotetext{
${ }^{1}$ School of Water Resources and Environment, China University of Geosciences, Beijing 100083, China
}

${ }^{2}$ State Key Laboratory of Biogeology and Environmental Geology, China University of Geosciences, Beijing 100083, China

${ }^{3}$ School of Earth Science and Resources, China University of Geosciences, Beijing 100083, China

* Correspondence: Hailiang Dong State Key Laboratory of Biogeology and Environmental Geology China University of Geosciences Beijing 100083, Tel: +86-10-82320969 E-mail address: dongh@cugb.edu.cn Revised for Environmental Science \& Technology November 4, 2019

Total number of pages: 19

Total number of figures: 12 


\section{Section S1: Preparation of chemically reduced NAu-2 (rNAu-2)}

Purchased NAu-2 was manually ground to powder, and suspended into $0.5 \mathrm{M}$ $\mathrm{NaCl}$ solution with continuous stirring for at least 24 hours in order to saturate the interlayer cations of NAu-2 with $\mathrm{Na}^{+}$. Sodium-saturated NAu-2 slurry was centrifugated to separate $0.02-0.5 \mu \mathrm{m}$ size-fraction. The separated clay suspension was dialyzed with $\mathrm{MQ}-\mathrm{H}_{2} \mathrm{O}(18.2 \mathrm{M} \Omega)$ to remove excess chloride ion $\left(\mathrm{Cl}^{-}\right)$, and was freezedried for later use.

Chemically reduced NAu-2 (referred to as $\mathrm{rNAu}-2$ ) was prepared by using the citrate-bicarbonate-dithionite (CBD) method. ${ }^{1}$ Specifically, $100 \mathrm{ml}$ clay slurry $(10 \mathrm{~g} / \mathrm{L})$ was purged with nitrogen gas $\left(\mathrm{N}_{2}\right)\left(99.999 \%\right.$ purity) for at least 30 minutes in a $100{ }^{\circ} \mathrm{C}$ water-bath. Four grams of sodium dithionite $\left(\mathrm{Na}_{2} \mathrm{~S}_{2} \mathrm{O}_{4}\right)$ was added into clay suspension subsequently to initiate the reduction reaction. The reaction bottle was sealed immediately with a rubber stopper and placed in a $70{ }^{\circ} \mathrm{C}$ incubator for at least 24 hours to achieve the maximum extent of reduction.

The reduced NAu-2 was washed 3 times with deoxygenated MQ- $\mathrm{H}_{2} \mathrm{O}(18.2 \mathrm{M} \Omega)$ to remove excess reducing agents and any aqueous Fe released from NAu-2 dissolution (less than $2-3 \%) .{ }^{1}$ The structural Fe(II) and total Fe concentrations of washed rNAu-2 were measured with 1,10-phenanthroline method. ${ }^{2}$ (see details in SI Section S5). The reduction extent of the washed $\mathrm{rNAu}-2$ was calculated (i.e., the ratio of $\mathrm{Fe}(\mathrm{II})$ concentration to total $\mathrm{Fe}$ concentration in $\mathrm{rNAu}-2, \sim 63 \%$ in this study). The washed rNAu-2 stock solution was stored under anaerobic condition for further experiments.

\section{Section S2: Sampling methods}


At each time-point, $0.7 \mathrm{ml}$ sample was collected from reaction tube with 1-mL sterilized syringe (purged with $\mathrm{N}_{2} / \mathrm{H}_{2}$ gas mix for 30 seconds) and centrifuged at 14,000 g for 10 minutes in a glove box $\left(95 \% \mathrm{~N}_{2}\right.$ and $5 \% \mathrm{H}_{2}$, Coy Laboratory Products, Grass Lake, Michigan). The supernatant was filtered through a $0.22 \mu \mathrm{m}$ nylon-filter and stored at $4{ }^{\circ} \mathrm{C}$ for further analysis (e.g., concentrations of aqueous $\mathrm{Cr}(\mathrm{VI})$, ligands, and total aqueous $\mathrm{Cr}$ ). The clay pellets were collected and washed 3 times with deoxygenated MQ- $\mathrm{H}_{2} \mathrm{O}$ to eliminate the possible effects of sorbed $\mathrm{Cr}(\mathrm{VI})$ on the following $\mathrm{Fe}(\mathrm{II})$ measurement.

\section{Section S3: Determination of aqueous Cr(VI) concentration}

Aqueous $\mathrm{Cr}(\mathrm{VI})$ concentration was determined with the diphenylcarbazide colorimetric method (DPC). ${ }^{3}$ Briefly, $0.1 \mathrm{ml}$ filtrate was mixed with $0.25 \mathrm{ml}$ color developing agent in $4.9 \mathrm{ml} \mathrm{MQ}-\mathrm{H}_{2} \mathrm{O}$. The mixture was placed in the dark for 10 minutes and absorbance was read at $540 \mathrm{~nm}$ on a UV-Vis spectrophotometer (UV-2550, SHIMADZU). The diphenylcarbazide color developer was prepared freshly by dissolving $0.1 \mathrm{~g}$ 1,5-diphenylcarbazide into $25 \mathrm{ml}$ acetone, and sequentially adding 25 $\mathrm{ml} \mathrm{MQ}-\mathrm{H}_{2} \mathrm{O}, 6.25 \mathrm{ml} \mathrm{H}_{2} \mathrm{SO}_{4}$, and $6.25 \mathrm{ml} \mathrm{H}_{3} \mathrm{PO}_{4}{ }^{3}$

\section{Section S4: Determination of aqueous $\mathrm{Cr}$ and Fe concentrations}

At the end of each $\mathrm{Cr}(\mathrm{VI})$ spike, total aqueous $\mathrm{Cr}$ and $\mathrm{Fe}$ concentrations were measured with inductively coupled plasma optical emission spectroscopy (ICP-OES, Icap 6300, Thermo). Suspension samples were filtrated through a $0.22 \mu \mathrm{m}$ nylon-filter and diluted with $3 \% \mathrm{HNO}_{3}$ before analysis. Standard solution was prepared by dilution of stock solution (1000 ppm) using 3\% $\mathrm{HNO}_{3}$. 


\section{Section S5: Concentration measurements of structural Fe(II), total Fe in rNAu-2,} and aqueous $\mathrm{Fe}^{2+}$

The concentration of structural Fe(II) in solid rNAu-2 was measured at the end of each $\mathrm{Cr}(\mathrm{VI})$ spike by using 1,10-phenanthroline method to calculate the molar ratios of $\mathrm{Fe}(\mathrm{II})$ oxidized to $\mathrm{Cr}(\mathrm{VI})$ reduced in the reaction systems. ${ }^{2}$ Briefly, clay suspension samples were digested with a mixture of $\mathrm{HF}$ and $\mathrm{H}_{2} \mathrm{SO}_{4}$ at boiling temperature, and a color indicator was added. The color developer was prepared freshly by dissolving $1 \mathrm{~g}$ 1,10-phenanthroline in $10 \mathrm{ml} \mathrm{95 \%} \mathrm{ethanol.} \mathrm{After} \mathrm{development} \mathrm{of} \mathrm{the} \mathrm{color,} \mathrm{the}$ absorbance at $510 \mathrm{~nm}$ was read on a spectrophotometer (UV-2550, SHIMADZU). The $\mathrm{Fe}(\mathrm{II})$ concentration was obtained based on a pre-established conversion curve between $\mathrm{Fe}(\mathrm{II})$ concentration and absorbance using ferrous ethylenediammonium sulfate tetrahydrate $\left[\mathrm{FeC}_{2} \mathrm{H}_{4}\left(\mathrm{NH}_{3}\right)_{2}\left(\mathrm{SO}_{4}\right)_{2} \cdot 4 \mathrm{H}_{2} \mathrm{O}\right.$, Sigma-Aldrich] as a standard. For detection of total structural $\mathrm{Fe}$ in $\mathrm{rNAu}-2$, the $\mathrm{Fe}(\mathrm{III})$ in $\mathrm{HF}-\mathrm{H}_{2} \mathrm{SO}_{4}$ digested mixture was reduced to $\mathrm{Fe}(\mathrm{II})$ by $10 \%$ hydroxylamine hydrochloride $\left(\mathrm{NH}_{3} \mathrm{OHCl}\right.$, Sigma-Aldrich). For aqueous $\mathrm{Fe}^{2+}-\mathrm{Cr}(\mathrm{VI})$ reaction experiments, aqueous $\mathrm{Fe}^{2+}$ was also measured with the same method at the end of each spike to calculate the corresponding molar ratios of aqueous $\mathrm{Fe}^{2+}$ oxidized to $\mathrm{Cr}(\mathrm{VI})$ reduced.

\section{Section S6: Determination of organic ligand concentration}

Time-course changes of organic ligand concentrations were monitored by high performance liquid chromatography (HPLC LC-20A, SHIMADZU) equipped with a UV detector. For detection of ligands including tartrate, malate, succinate, lactate, pyruvate, and propionate, the mobile phase was $2.5 \mathrm{mM} \mathrm{H}_{2} \mathrm{SO}_{4}$ with a flow rate of 1.0 
$\mathrm{ml} / \mathrm{min}$. The chromatographic column was a Phenomenex Rezex ROA-organic acid $(8 \%)$ column $(8 \mu \mathrm{m}$ diameter, length $\times$ width of $300 \times 7.8 \mathrm{~mm})$. These organic ligands were quantified at $214 \mathrm{~nm}$. DL-sodium tartrate $\left(\mathrm{C}_{4} \mathrm{H}_{4} \mathrm{O}_{6} \mathrm{Na}_{2}\right)$, L-malic acid $\left(\mathrm{C}_{4} \mathrm{H}_{6} \mathrm{O}_{5}\right)$, sodium succinate $\left(\mathrm{C}_{4} \mathrm{H}_{4} \mathrm{O}_{4} \mathrm{Na}_{2}\right)$, sodium lactate $\left(\mathrm{C}_{3} \mathrm{H}_{5} \mathrm{O}_{3} \mathrm{Na}\right)$, sodium pyruvate $\left(\mathrm{C}_{3} \mathrm{H}_{3} \mathrm{O}_{3} \mathrm{Na}\right)$, and sodium propionate $\left(\mathrm{C}_{3} \mathrm{H}_{5} \mathrm{O}_{2} \mathrm{Na}\right)$ were used as standards.

\section{Section S7: Detection of mandelate, methyl mandelate, and their oxidation} products

Concentrations of mandelate, methyl mandelate and their possible oxidation products (i.e., benzaldehyde, phenylglyoxlate, and benzoate) in the presence of $\mathrm{Cr}(\mathrm{VI})$ and rNAu-2 were analyzed with HPLC (LC-20A, SHIMADZU) equipped with a C18 column (Agilent ZORBAX Eclipse Plus, $5 \mu \mathrm{m}$ diameter, length $\times$ width of $150 \times 4.6$ $\mathrm{mm})$ at $40{ }^{\circ} \mathrm{C}$ and a UV detector. ${ }^{4,5}$ The mobile eluent was $25 \%$ acetonitrile and $75 \%$ water solution containing $0.1 \%(\mathrm{v} / \mathrm{v})$ trifluoroacetic acid (TFA) with a flow rate of 1.0 $\mathrm{ml} / \mathrm{min}$. D,L-mandelic acid $\left[\mathrm{C}_{6} \mathrm{H}_{5} \mathrm{C}(\mathrm{OH}) \mathrm{HCOOH}\right]$, methyl DL-mandelate $\left[\mathrm{C}_{6} \mathrm{H}_{5} \mathrm{C}(\mathrm{OH}) \mathrm{HCOOCH}_{3}\right]$, phenylglyoxylic acid $\left[\mathrm{C}_{6} \mathrm{H}_{5} \mathrm{C}(\mathrm{O}) \mathrm{COOH}\right]$, benzaldehyde $\left(\mathrm{C}_{6} \mathrm{H}_{5} \mathrm{CHO}\right)$, and benzoic acid $\left(\mathrm{C}_{6} \mathrm{H}_{5} \mathrm{COOH}\right)$ were used to prepare standard curves. $\mathrm{A}$ mixed standard solution was used to check if all these compounds could be separated under the applied conditions. Results showed that the conditions were efficient for separation, and the retention time was $3.00 \mathrm{~min}$ for mandelic acid, $3.452 \mathrm{~min}$ for phenylglyoxylic acid, 5.386 min for methyl mandelate, $6.189 \mathrm{~min}$ for benzoic acid, and $9.205 \mathrm{~min}$ for benzaldehyde. All organics were quantified at $230 \mathrm{~nm}$ except phenylglyoxylic acid at $254 \mathrm{~nm}$. 
In the presence of certain organic ligands, the reduced $\mathrm{Cr}(\mathrm{VI})$ products were likely to complex with organics, forming soluble $\mathrm{Cr}(\mathrm{III})$-organic complexes with characteristic adsorption peaks. Thus, spectra of soluble reaction products at the end of each $\mathrm{Cr}(\mathrm{VI})$ spike were recorded on a UV-Vis spectrophotometer (UV-2550, SHIMADZU) over a wavelength range of $300 \mathrm{~nm}$ to $800 \mathrm{~nm}$. Chromium trichloride hexahydrate $\left(\mathrm{CrCl}_{3} \cdot 6 \mathrm{H}_{2} \mathrm{O}\right)$ and chromium nitrate nonahydrate $\left[\mathrm{Cr}\left(\mathrm{NO}_{3}\right)_{3} \cdot 9 \mathrm{H}_{2} \mathrm{O}\right]$ were used as inorganic $\mathrm{Cr}$ (III) standards. $\mathrm{Cr}$ (III)-tartrate and $\mathrm{Cr}$ (III)-malate complexes were applied as organo-Cr(III) standards. The inorganic $\mathrm{Cr}$ (III) standard solutions were freshly prepared by dissolving the $\mathrm{CrCl}_{3} \cdot 6 \mathrm{H}_{2} \mathrm{O}$ and $\mathrm{Cr}\left(\mathrm{NO}_{3}\right)_{3} \cdot 9 \mathrm{H}_{2} \mathrm{O}$ into $0.01 \mathrm{~N} \mathrm{HCl}$ solution $(10 \mathrm{mM})$ in order to avoid hydrolysis. The $\mathrm{Cr}(\mathrm{III})$-tartrate and malate complexes were prepared by mixing $10 \mathrm{mM} \mathrm{CrCl}_{3} \cdot 6 \mathrm{H}_{2} \mathrm{O}$ with either $30 \mathrm{mM}$ tartrate or malate at $\mathrm{pH} 4$ for 48 hours in the dark, respectively. ${ }^{6}$ The expected molar ratio of $\mathrm{Cr}(\mathrm{III})$ to ligand was 1:2 for tartrate, ${ }^{6}$ and 1:1.16 for malate. ${ }^{7}$ Thus, excess tartrate and malate were used to guarantee that all $\mathrm{Cr}^{3+}$ ions were complexed. ${ }^{6,7}$

\section{Section S9: Characterization of insoluble $\mathrm{Cr}(\mathrm{VI})$ reduction products} determined by using X-ray photoelectron spectroscopy (XPS). The XPS analyses were carried out on a Thermo Scientific Escalab 250Xi spectrometer using a monochromatic energy of $30 \mathrm{eV}$. The XPS data were analyzed by using XPSPEAK 4.1. Chromium hydroxide $\left[\mathrm{Cr}(\mathrm{OH})_{3}\right]$, chromium oxide $\left(\mathrm{Cr}_{2} \mathrm{O}_{3}\right)$, and potassium chromate $\left(\mathrm{K}_{2} \mathrm{CrO}_{4}\right)$ 
(analytical grade, purchased from Shanghai Macklin Biochemical Co., Ltd.) were used

141 as standard references.

\section{Section S10: Identification and quantification of $\mathrm{Cr}(\mathrm{V})$ intermediate}

In order to explore the mechanism of synergistic $\mathrm{Cr}(\mathrm{VI})$ reduction by $\mathrm{rNAu}-2$ and organic ligands, the transient $\mathrm{Cr}(\mathrm{V})$ intermediate in the reaction systems was identified with low temperature $(77 \mathrm{~K})$ electron paramagnetic resonance (EPR) spectroscopy. For EPR measurement, rNAu-2 [17.6 mM structural Fe(II)] and ligand (10 mM) suspension was prepared in $200 \mathrm{mM}$ MES buffer solution in 28-mL Balch tubes. Subsequently, a proper amount of $\mathrm{Cr}(\mathrm{VI})$ stock solution was injected into the reaction tubes to initiate the reaction with an initial concentration of $5 \mathrm{mM}$. Approximately $100 \mu 1$ sample was immediately collected from the tubes with 1-mL syringe, and quickly transferred into a quartz capillary for analysis at $77 \mathrm{~K}$. EPR spectra were obtained using a Bruker A30010/12 spectrometer (Bruker BioSpin Corporation, Billerica, MA, USA). The total amount of time from injection of $\mathrm{Cr}(\mathrm{VI})$ stock solution into the reaction tubes to the start of EPR data collection was 30-40 seconds.

For quantitative analysis of $\mathrm{Cr}(\mathrm{V})$ concentration by EPR spectroscopy, sodium bis(2-hydroxy-2-methylbutyrato)oxochromate(V) (Sigma-Aldrich) was used to create a standard curve. ${ }^{8}$ The $\mathrm{Cr}(\mathrm{V})$ concentration was linearly correlated with the peak area under the EPR first-derivative spectrum $\left(\mathrm{R}^{2}=0.9933\right.$, data not shown $) .{ }^{9}$ Thus, EPR signals in all samples were converted to $\mathrm{Cr}(\mathrm{V})$ concentrations based on the corresponding peak areas of EPR first-derivative spectra. ${ }^{9}$

The $\mathrm{Cr}(\mathrm{V})$ measurements were conducted with the following EPR settings: 
microwave frequency $=9.851 \mathrm{GHz}$, microwave power $=19.27 \mathrm{~mW}$, receiver gain $=1.0$

$163 \times 10^{3}$, modulation amplitude $=1.0 \mathrm{G}$, center field $=3510 \mathrm{G}$, sweep width $=100 \mathrm{G}$, and 164 sweep time $=60.42$ s. The $\operatorname{Cr}($ III $)$ measurements were made with the following 165 parameters: microwave frequency $=9.851 \mathrm{GHz}$, microwave power $=19.34 \mathrm{~mW}$, 166 receiver gain $=1.0 \times 10^{3}$, modulation amplitude $=1.0 \mathrm{G}$, center field $=3610 \mathrm{G}$, sweep 167 width $=3000 \mathrm{G}$, and sweep time $=60.42 \mathrm{~s}$. 

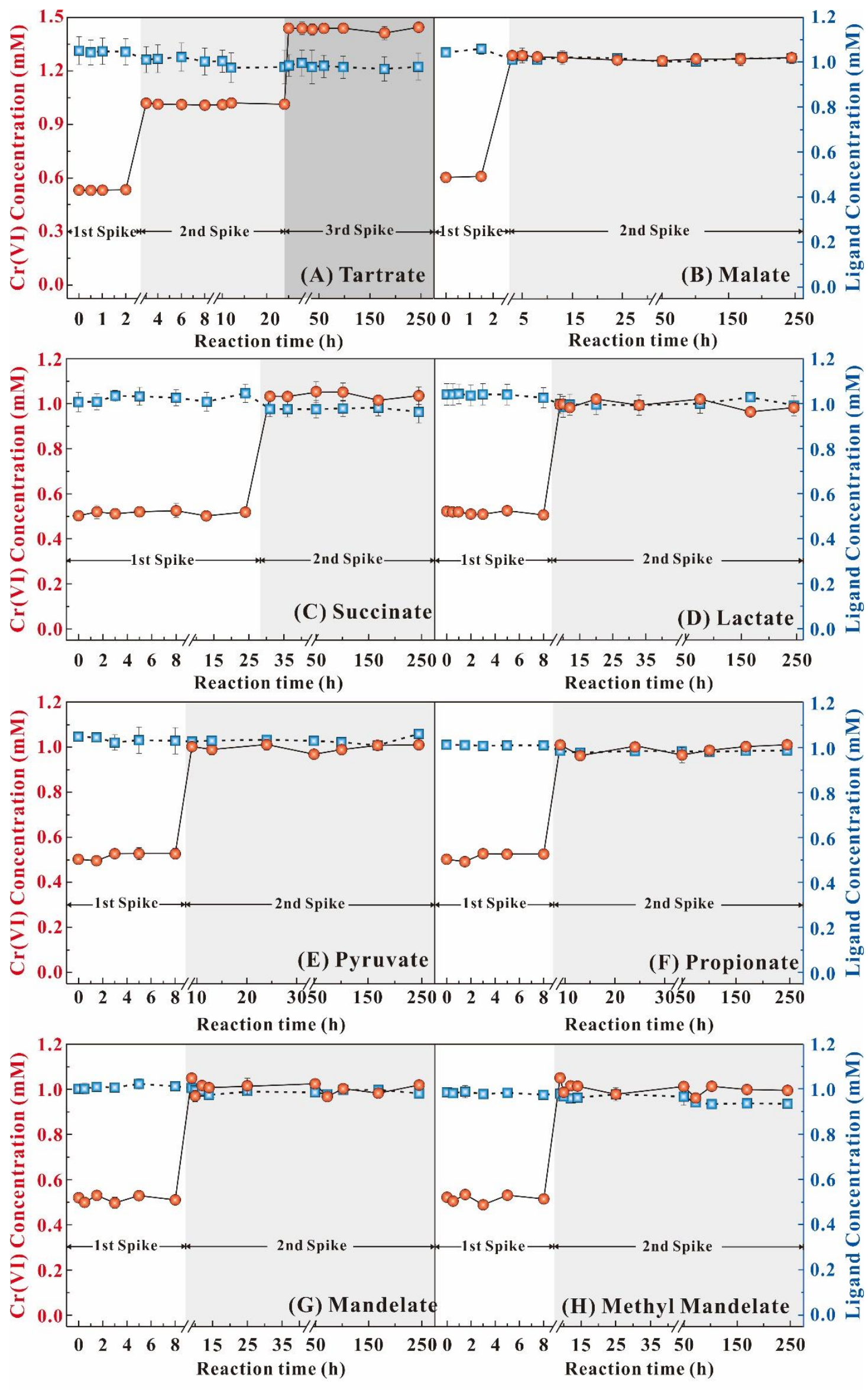

$\rightarrow-\operatorname{Cr}($ VI) Concentration $\quad \cdot-\cdot \cdot$ Ligand Concentration 
Figure S1. Time-course changes of $\mathrm{Cr}(\mathrm{VI})$ and organic ligand concentrations in the groups of $\mathrm{Cr}(\mathrm{VI})+$ Ligand. Different Cr(VI) spikes were labelled with different levels of shades according to the timing of $\mathrm{Cr}(\mathrm{VI})$ addition in $\mathrm{Cr}(\mathrm{VI})+$ Ligand groups. The left and right $\mathrm{Y}$-axes represent the concentrations of $\mathrm{Cr}(\mathrm{VI})$ and organic ligand, respectively. Under the experimental conditions used in the present study ( $\mathrm{pH}=6.0$, in the dark), none of the selected organic ligands was reactive towards $\mathrm{Cr}(\mathrm{VI})$ reduction, consistent with a previous study in which the half-life of $\mathrm{Cr}(\mathrm{VI})$ reduction by organic compounds at circumneutral $\mathrm{pH}$ ranges from months to years. ${ }^{10}$

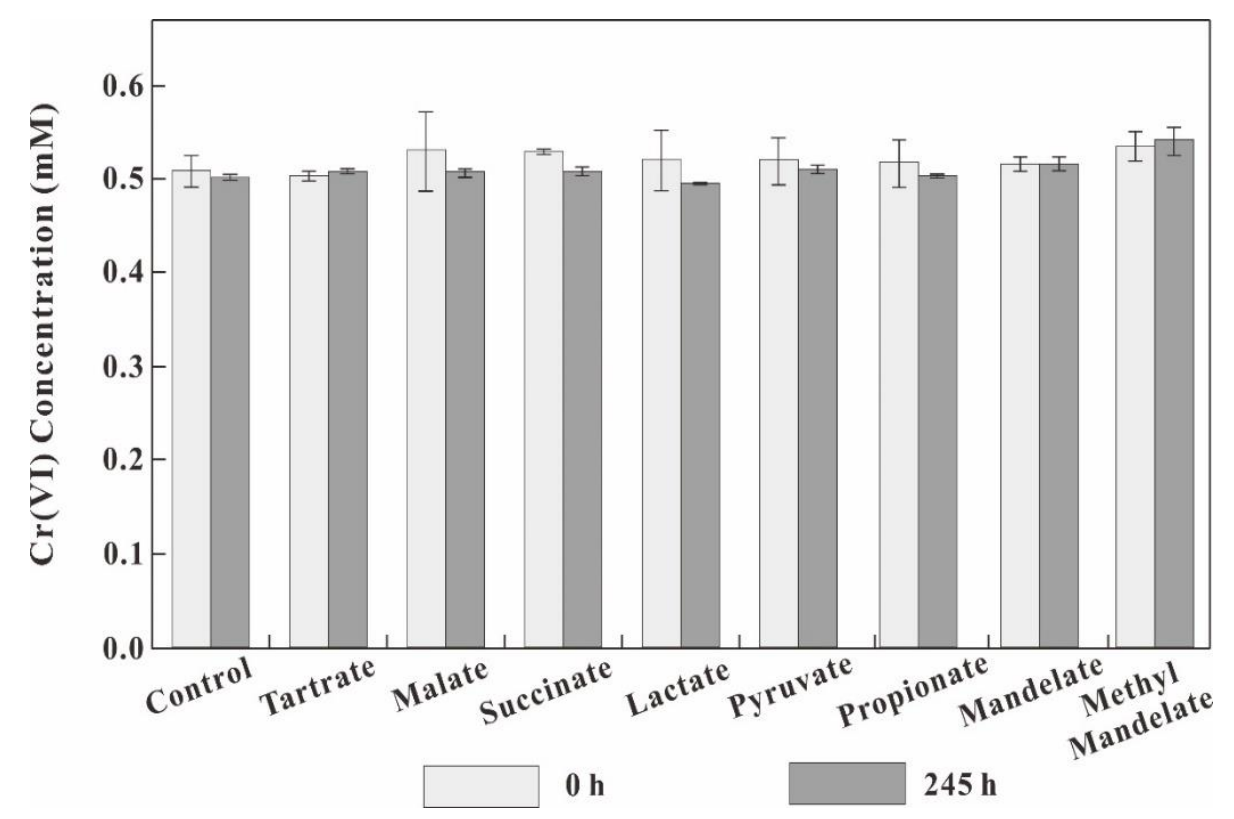

Figure S2. Cr(VI) concentration at the beginning (i.e., 0 h) and end (i.e., 245 h) of the reaction in the groups of $\mathrm{NAu}-2+\mathrm{Cr}(\mathrm{VI})$ (control) and $\mathrm{NAu}-2+\mathrm{Cr}(\mathrm{VI})+\mathrm{Ligand}$. The pristine NAu-2 alone or in combination with organic ligands did not significantly remove any $\mathrm{Cr}(\mathrm{VI})$ from aqueous solution at the end of reaction. The absence of mineral surface-catalyzed $\mathrm{Cr}(\mathrm{VI})$ removal by ligands was likely due to the circumneutral $\mathrm{pH}$ condition used in the present work $(\mathrm{pH}=6)$, which is higher than the reported highest 
$\mathrm{pH}$ value required for montmorillonite surface to catalyze $\mathrm{Cr}(\mathrm{VI})$ reduction by organic compounds $(\mathrm{pH}=4.7){ }^{11}$

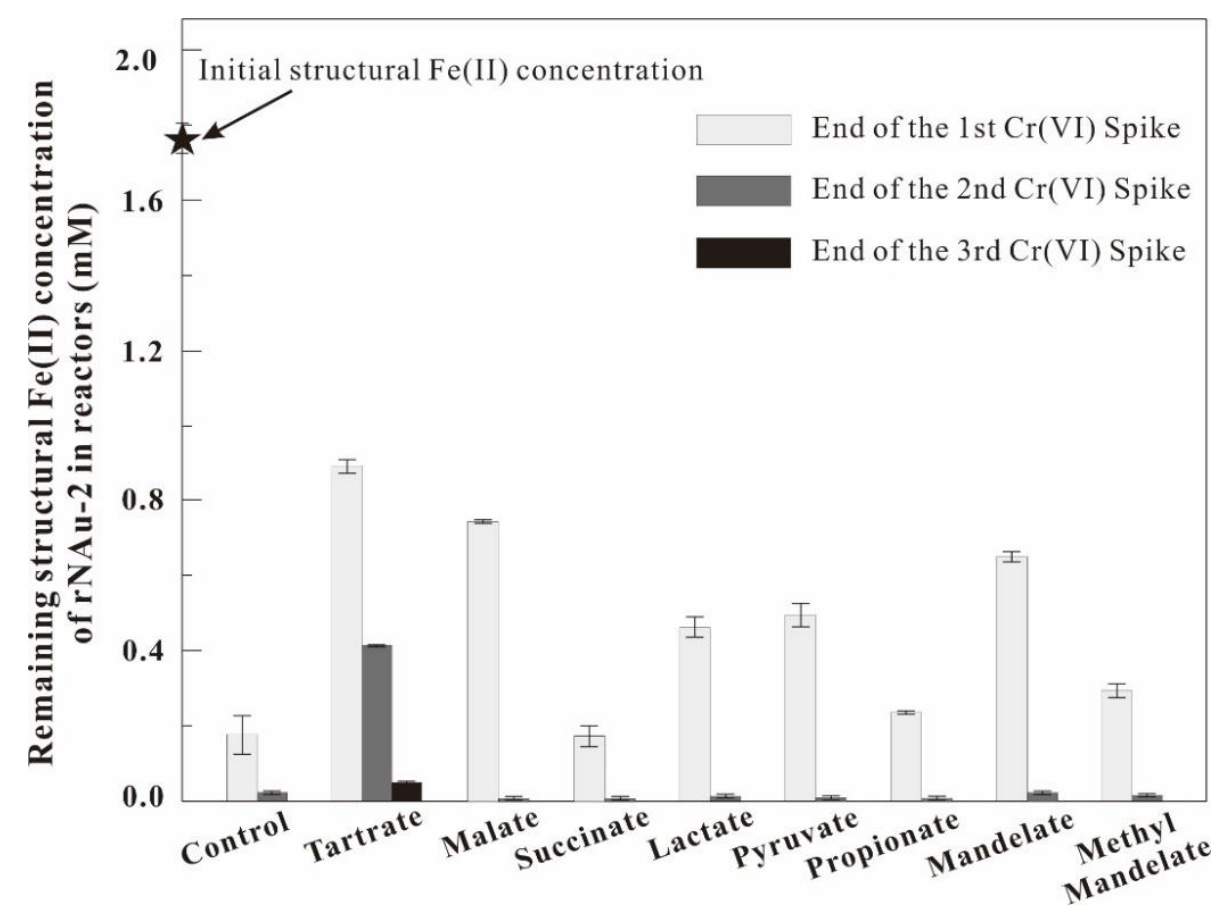

Figure S3. The remaining structural Fe(II) concentration at the end of each $\mathrm{Cr}(\mathrm{VI})$ spike.

The initial structural Fe(II) concentrations in all reactors were the same $(\sim 1.76 \mathrm{mM})$.

Despite the same amount of $\mathrm{Cr}(\mathrm{VI})$ removal (i.e., $0.5 \mathrm{mM}$ ) in all reactors at the end of the first $\mathrm{Cr}(\mathrm{VI})$ spike, more structural $\mathrm{Fe}(\mathrm{II})$ in $\mathrm{rNAu}-2$ remained in the presence of stimulatory ligands (i.e., tartrate, malate, lactate, pyruvate, and mandelate) relative to groups of control and inhibitory ligands (i.e., succinate, propionate, and methyl mandelate). Moreover, a considerable amount of structural Fe(II) still remained at the end of the second $\mathrm{Cr}(\mathrm{VI})$ spike in the tartrate group, which was responsible for the $\mathrm{Cr}(\mathrm{VI})$ reduction in the third $\mathrm{Cr}(\mathrm{VI})$ spike in this group (Figure 1A). 


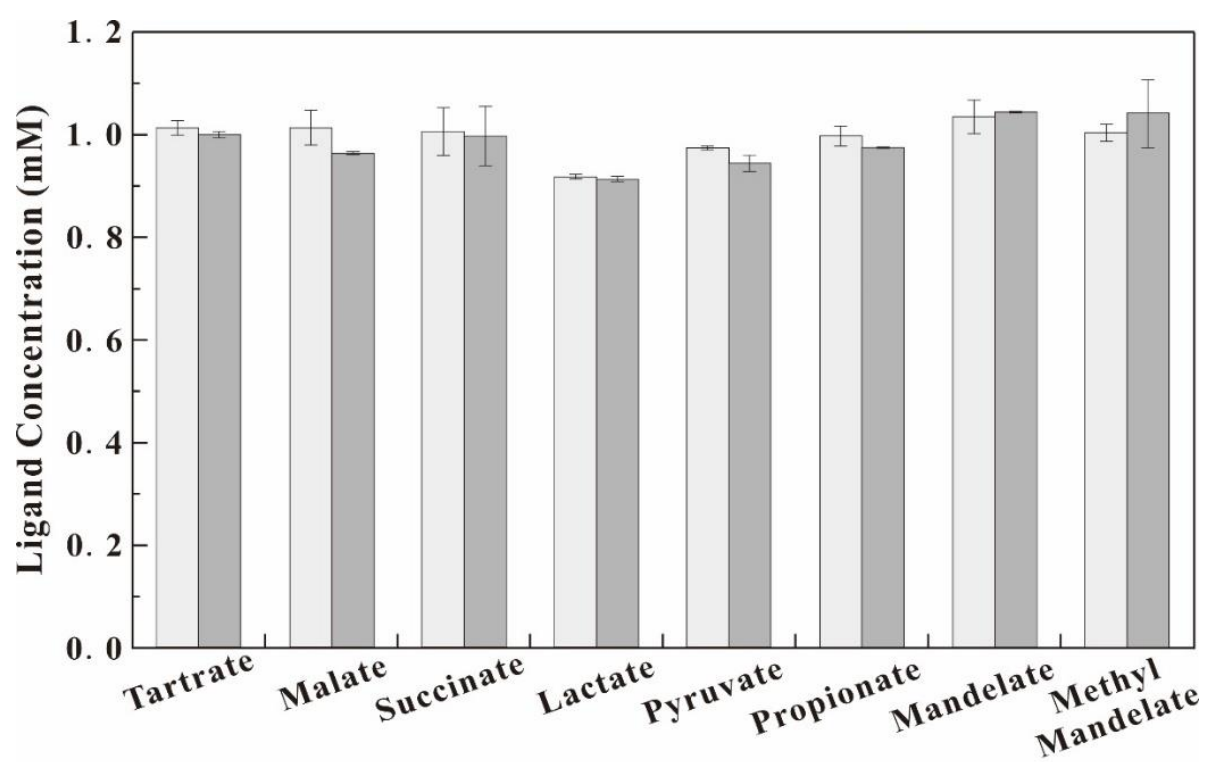

Figure S4. Concentrations of organic ligands at the beginning (i.e., $0 \mathrm{~h}$ ) and end (i.e.,

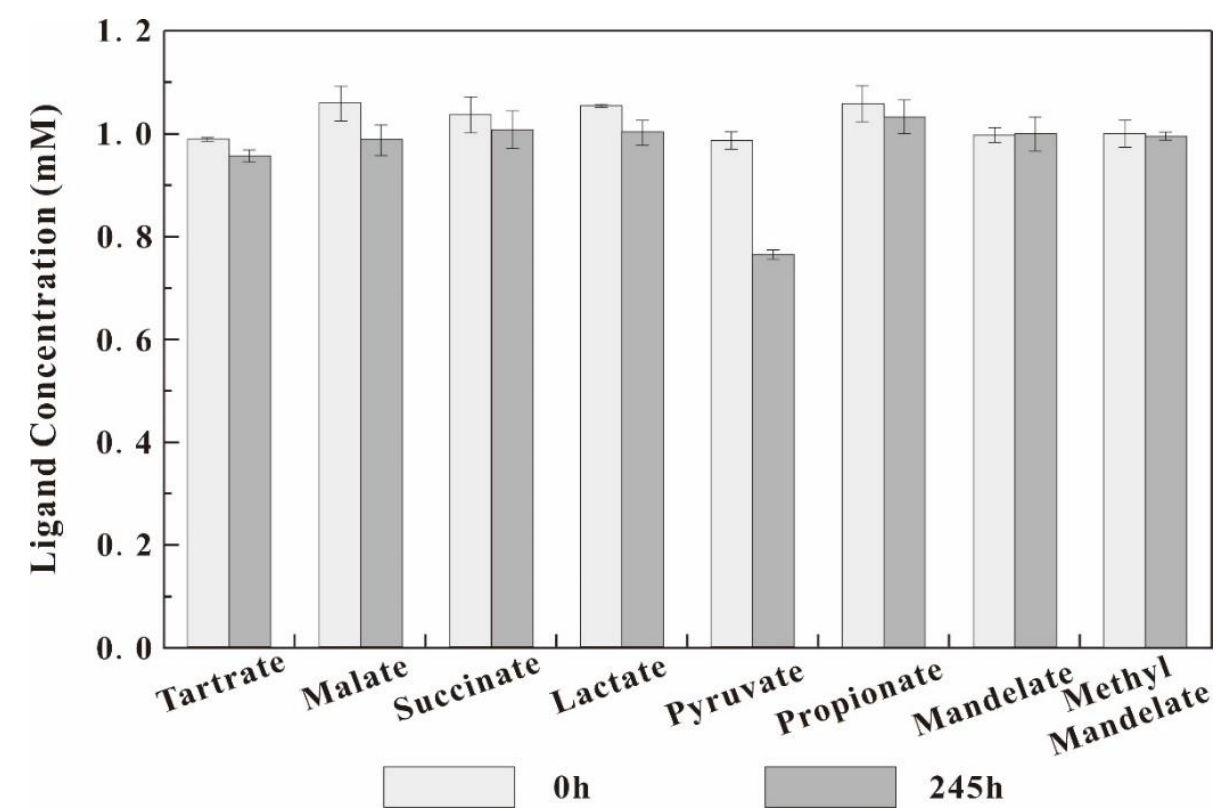

Figure S5. Concentrations of organic ligands at the beginning (i.e., $0 \mathrm{~h}$ ) and end (i.e., 


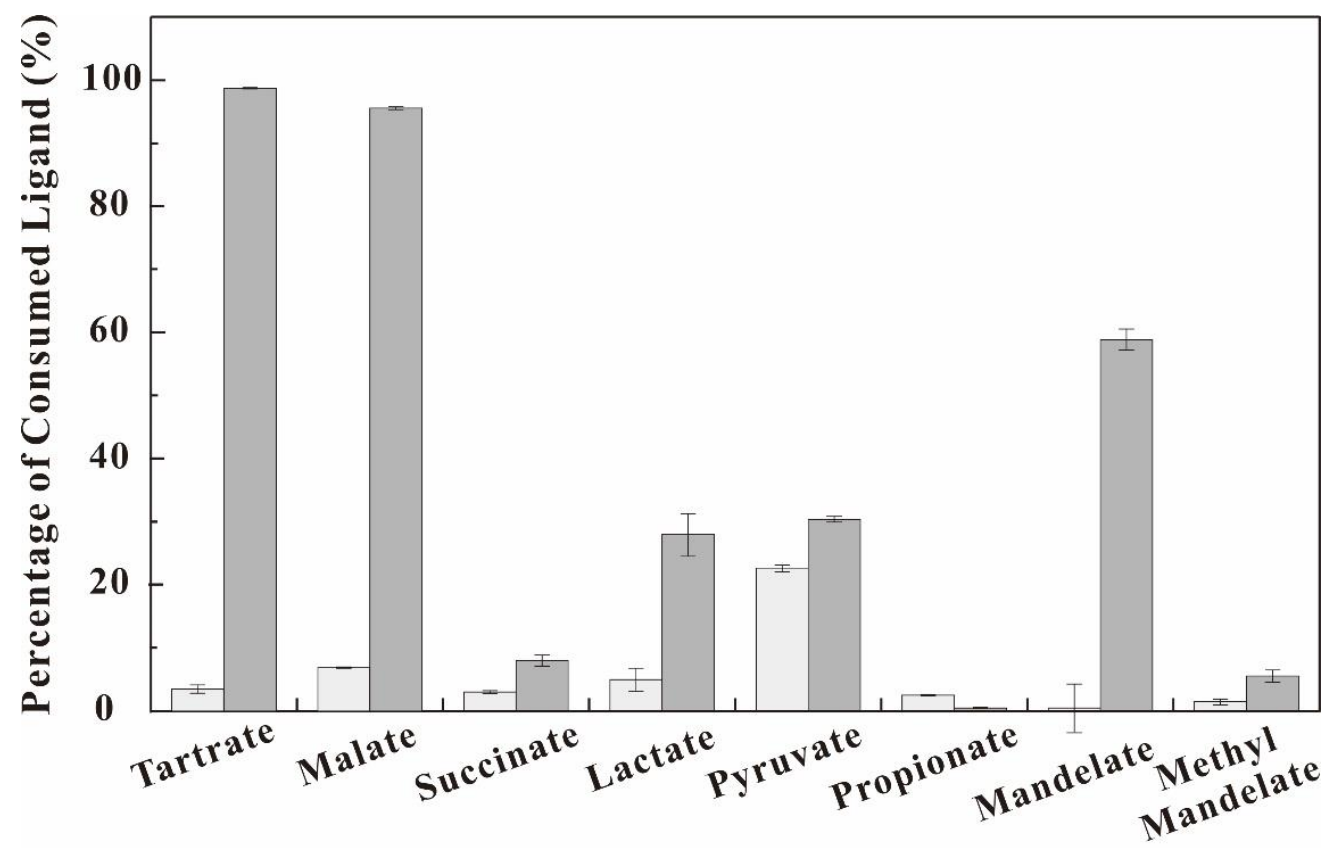

210 Figure S6. Comparisons in the percentage of consumed ligands between rNAu-

211 2+Ligand and rNAu-2+Cr(VI)+Ligand groups at the end of the reaction. Higher

212 percentages of ligands were consumed in the presence of both $\mathrm{rNAu}-2$ and $\mathrm{Cr}(\mathrm{VI})$ compared with rNAu-2 alone.

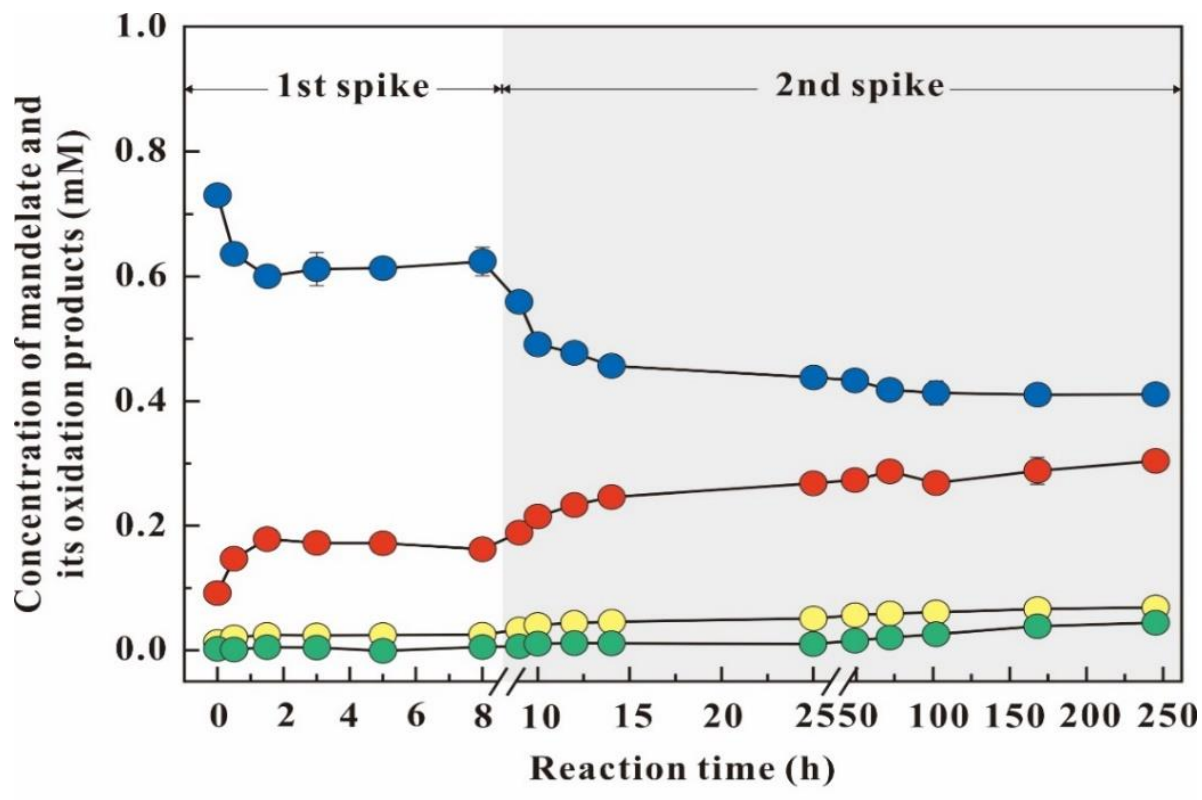


Figure S7. Time-course changes of concentrations of mandelate and its major oxidation products in $\mathrm{rAu}-2+\mathrm{Cr}(\mathrm{VI})+\mathrm{Mandelate}$ group at $\mathrm{pH} 6$.

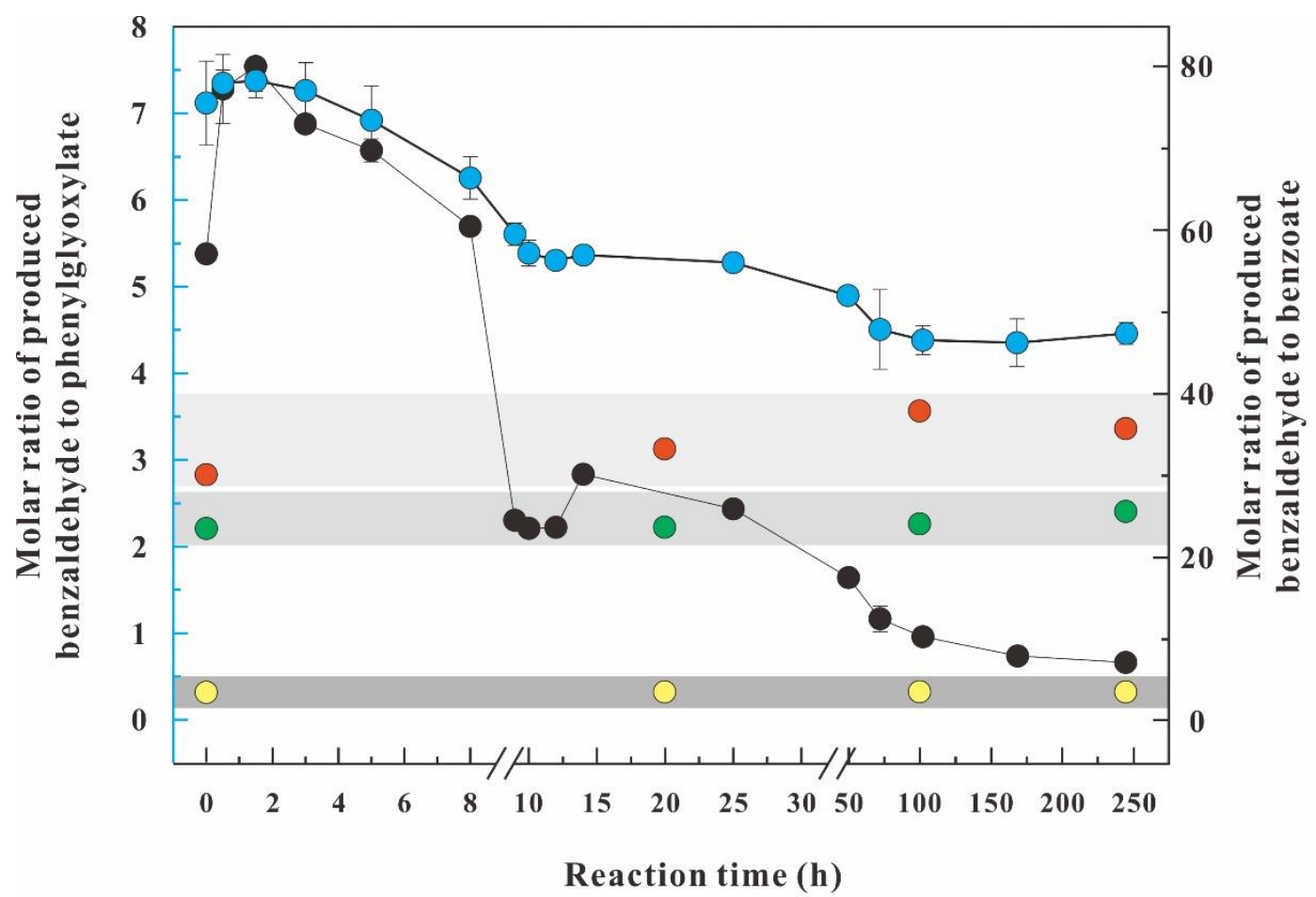

Benzaldehyde/Phenylglyoxylate: $\mathrm{rNAu}-2+\mathrm{Cr}(\mathrm{VI})+$ Mandelate $(\mathrm{pH}=6$, this study)

- Benzaldehyde/Benzoate: $\mathrm{rNAu}-2+\mathrm{Cr}(\mathrm{VI})+$ Mandelate $(\mathrm{pH}=6$, this study)

- Benzaldehyde/Phenylglyoxylate: $\mathrm{Cr}(\mathrm{VI})+$ Mandelate ( $\mathrm{pH}=0.3$, Ip and Rocek, 1979)

- Benzaldehyde/Phenylglyoxylate: $\mathrm{Cr}(\mathrm{VI})+$ Mandelate ( $\mathrm{pH}=\mathbf{2 . 3}$, Ip and Rocek, 1979)

221 Figure S8. Time-course changes of the molar ratios of produced benzaldehyde to phenylglyoxylate and benzaldehyde to benzoate in the group of rNAu$2+\mathrm{Cr}(\mathrm{VI})+$ Mandelate in comparison with literature data of direct/indirect $\mathrm{Cr}(\mathrm{VI})$ reduction by mandelate under acidic condition. ${ }^{4,5}$ 

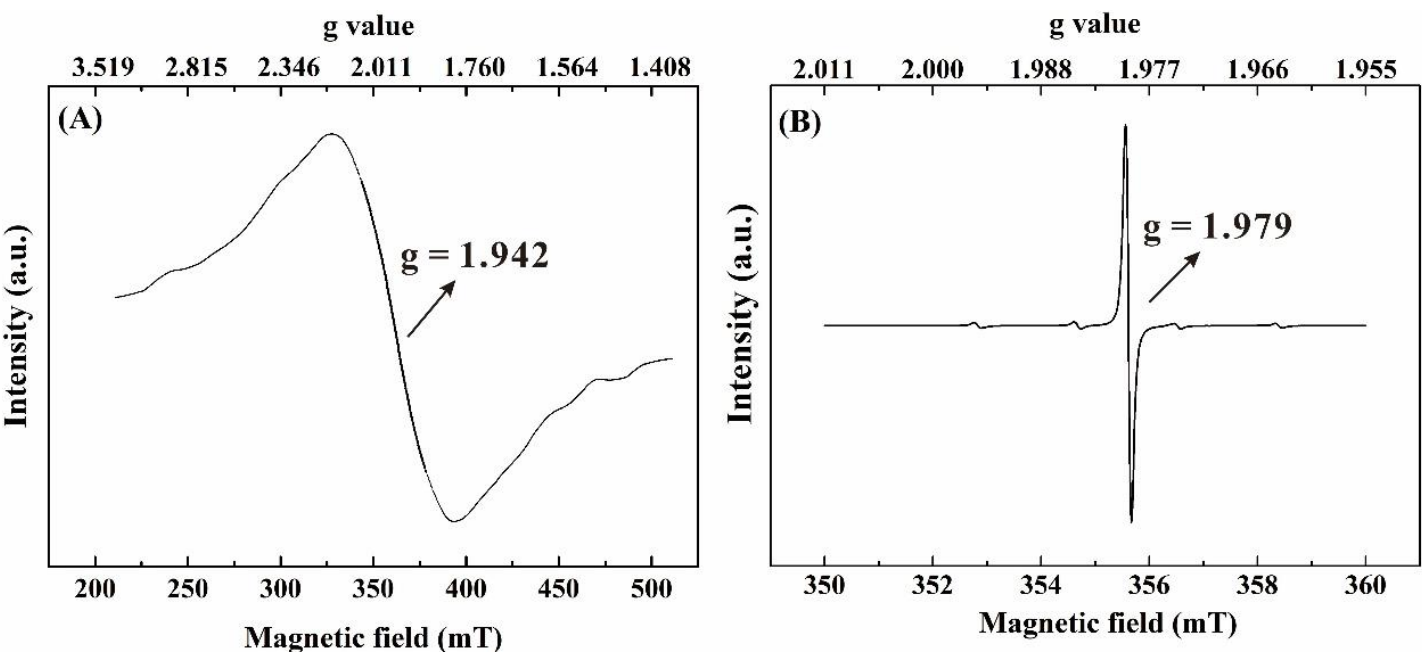

Figure S9. (A) Representative EPR spectrum of organo-Cr(III) standard [i.e., Cr(III)-

tartrate complex]. The complex was prepared by mixing $10 \mathrm{mM} \mathrm{CrCl}_{3} \cdot 6 \mathrm{H}_{2} \mathrm{O}$ with 30

$\mathrm{mM}$ tartrate at $\mathrm{pH} 4$ and by allowing the reaction to last for 48 hours in the dark. ${ }^{6}$ The organo-Cr(III) yields a broad peak with a line width of $\sim 65 \mathrm{mT}$ centered at $\mathrm{g}=1.942$,

Representative EPR spectrum of organo-Cr(V) standard [i.e., 5.67 mM sodium bis(2hydroxy-2-methylbutyrato)oxochromate(V) in $0.001 \mathrm{M} \mathrm{HClO}_{4}$ solution] (SigmaAldrich). ${ }^{13}$ The organo-Cr(V) produces a sharp peak with a line width of $\sim 0.11 \mathrm{mT}$ centered at $g=1.979 .{ }^{8}$ The conversion equation between magnetic field and $g$ value is $\mathrm{g}=[\mathrm{h} * \mathrm{nu}] /\left[\right.$ beta $\left.^{*} \mathrm{~B}_{0}\right]$. In this equation, $\mathrm{h}$ is the Planck's constant $\left(6.626^{*} 10^{-34} \mathrm{~J} / \mathrm{s}\right)$, nu is the spectrum frequency $\left(9.851 * 10^{9} \mathrm{~Hz}\right.$ in the present work), and beta is the Bohr magneton $\left(9.274 * 10^{-24} \mathrm{~J} / \mathrm{T}\right) . \mathrm{B}_{0}$ is the magnetic field $(\mathrm{T})$. 


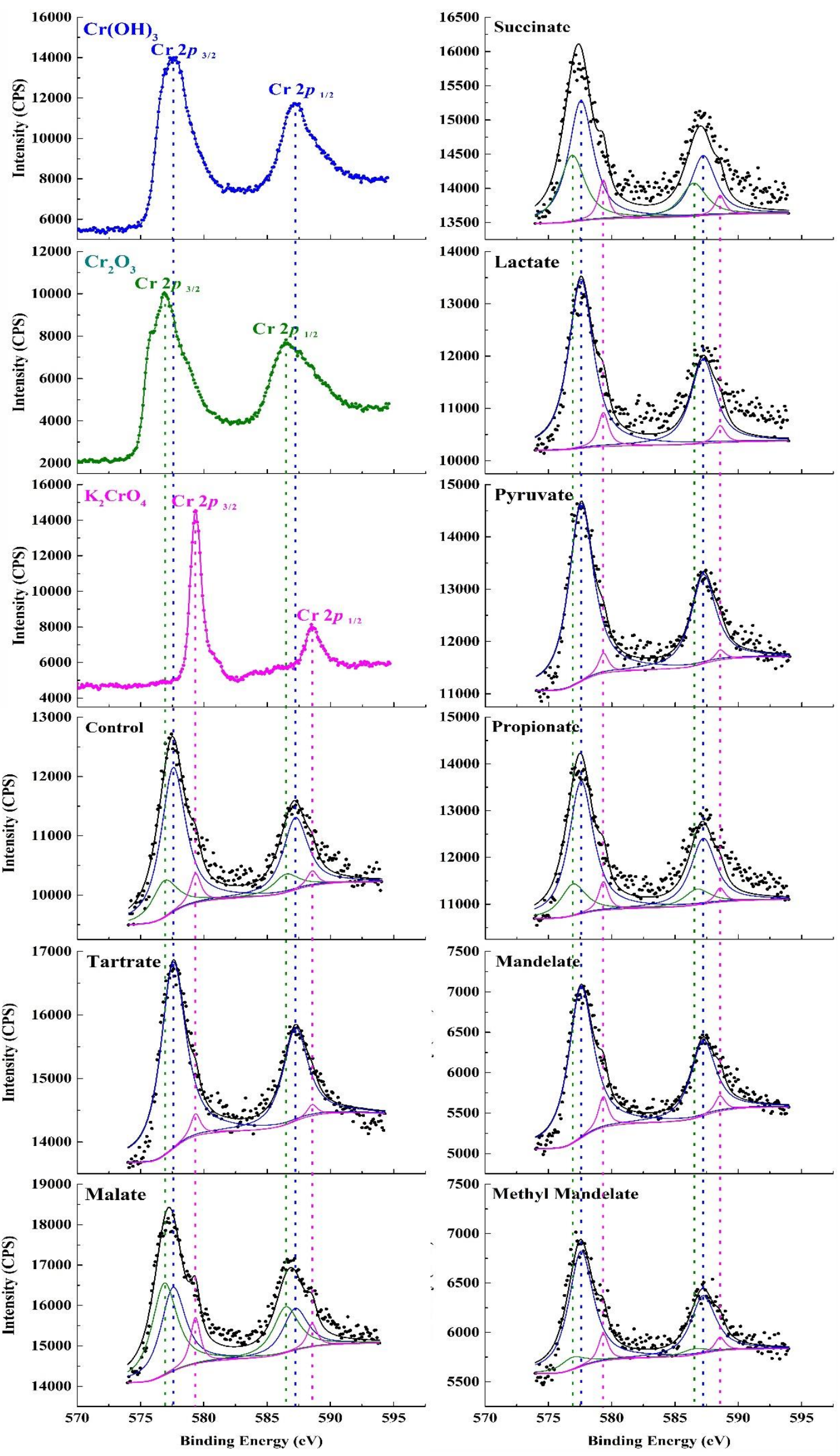


Figure S10. XPS Cr 2p spectra of solid products at the end of reduction reaction. The
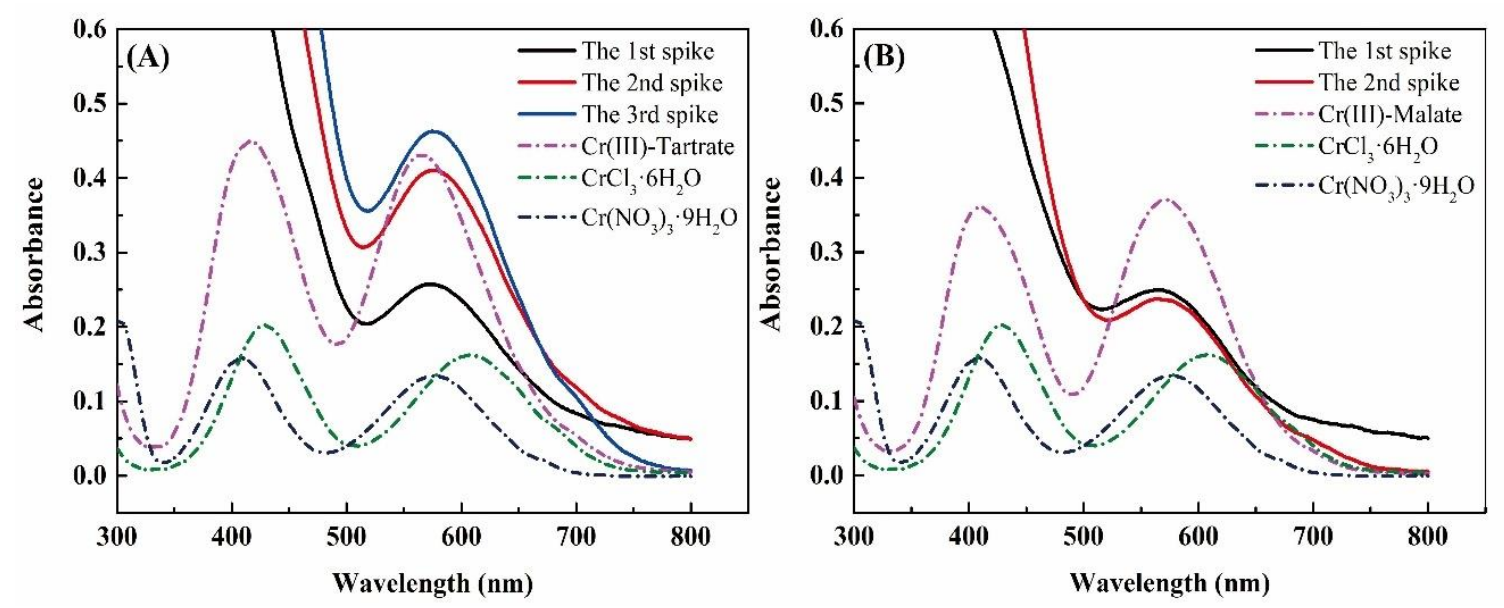

Figure S11. UV-Vis spectra of soluble Cr(VI) reduction end products in the groups of tartrate (A) and malate (B) at the end of each $\mathrm{Cr}(\mathrm{VI})$ spike. The two inorganic $\mathrm{Cr}(\mathrm{III})$ standards [i.e., $\mathrm{CrCl}_{3} \cdot 6 \mathrm{H}_{2} \mathrm{O}$ and $\mathrm{Cr}\left(\mathrm{NO}_{3}\right)_{3} \cdot 9 \mathrm{H}_{2} \mathrm{O}$ ] displayed quite different spectra due to the different main species in solution, i.e., $\mathrm{Cr}\left(\mathrm{H}_{2} \mathrm{O}\right)_{4} \mathrm{Cl}_{2}{ }^{+}$in $\mathrm{CrCl}_{3} \cdot 6 \mathrm{H}_{2} \mathrm{O}$ and $\mathrm{Cr}\left(\mathrm{H}_{2} \mathrm{O}\right)_{6}{ }^{3+}$ in $\mathrm{Cr}\left(\mathrm{NO}_{3}\right)_{3} \cdot 9 \mathrm{H}_{2} \mathrm{O} .{ }^{14}$ The $\mathrm{UV}$-Vis spectrum of $\mathrm{Cr}\left(\mathrm{NO}_{3}\right)_{3} \cdot 9 \mathrm{H}_{2} \mathrm{O}$ is often used to identify the presence of aqua-chromium(III) species. ${ }^{15,16}$ Whereas $\mathrm{CrCl}_{3} \cdot 6 \mathrm{H}_{2} \mathrm{O}$ is used as a reference to identify complexation of $\mathrm{Cr}(\mathrm{III})$ with organic ligands. If $\mathrm{Cr}$ (III) forms a complex with organics, the peak position of $\mathrm{Cr}$ (III) moves to a shorter 254 wavelength (i.e., left shift) compared with $\mathrm{CrCl}_{3} \cdot 6 \mathrm{H}_{2} \mathrm{O} \cdot{ }^{16,17}$ Moreover, this kind of left 255 shift was observed for the organo-Cr(III) standards [i.e., $\mathrm{Cr}$ (III)-tartrate and $\mathrm{Cr}$ (III)malate complexes]. 


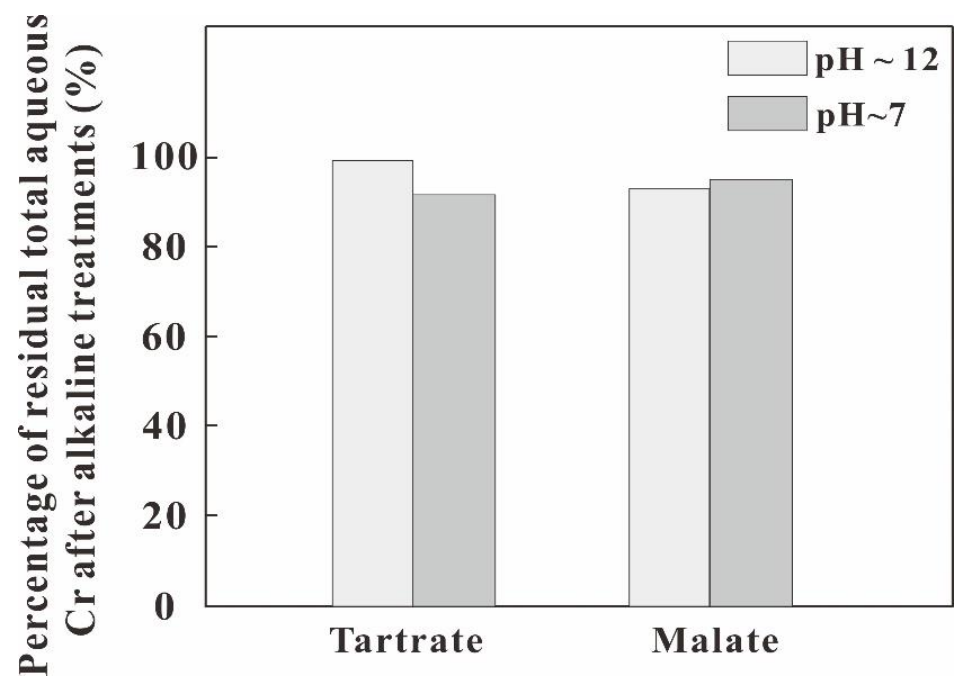

259 Figure S12. Percentage of residual total aqueous $\mathrm{Cr}$ as a result of alkaline precipitation

treatment of soluble $\mathrm{Cr}$ end products in tartrate and malate groups (i.e., adjusting $\mathrm{pH}$ to around 7 or 12 with $3 \mathrm{M} \mathrm{NaOH}$ ). There are slight decreases of aqueous $\mathrm{Cr}$ concentration after alkaline treatment, suggesting that a small fraction of $\mathrm{Cr}$ (III) may have been precipitated.

\section{References:}

1. Stucki, J. W.; Golden, D. C.; Roth, C. B. Preparation and handling of dithionite-reduced smectite suspensions. Clays Clay Miner. 1984, 32 (3), 191-197;

2. Amonette, J. E.; Templeton, J. C. Improvements to the quantitative assay of nonrefractory minerals for Fe(II) and total Fe using 1, 10-phenanthroline. Clays Clay Miner. 1998, 46 (1), 51-62; 3. Wang, Qi; Jin, L. The improvement in aqueous $\mathrm{Cr}(\mathrm{VI})$ measurement by the diphenylcarbazide method. Environmental Protection of Chemical Industry 2004, 24, 389-390 (In Chinese); 4. Deng, B.; Stone, A. T. Surface-catalyzed chromium(VI) reduction: the TiO2-Cr(VI)-mandelic acid system. Environ. Sci. Technol. 1996, 30 (2), 463-472; DOI 10.1021/es950156c. 5. Ip, D.; Rocek, J. Three electron oxidation. 16. chromic acid oxidation of mandelic acid. J. Am. Chem. Soc. 1979, 101 (21), 6311-6319; 6. Dai, R.; Yu, C.; Gou, J.; Lan, Y.; Mao, J. Photoredox pathways of Cr(III)-tartrate complexes and their impacting factors. J. Hazard. Mater. 2011, 186 (2-3), 2110-21116; DOI 10.1016/j.jhazmat.2010.12.127. complexes after chromate reduction in the presence of cellular organics. Environ. Sci. Technol. 2005, 39 (8), 2811-2817; DOI 10.1021/es048967g. 

over $\mathrm{TiO} 2$ particles in the presence of oxalate involvement of $\mathrm{Cr}(\mathrm{V})$ sepcies. Environ Sci Technol 2004,

286 38, 1589-1594;

287 10. Deng, B. Chromium(VI) reduction by naturally-occurring organic compounds: direct and surface288 catalyzed reactions. Ph.D. Dissertation, Johns Hopkins Univeristy, Baltimore, Maryland, 1995.

289 11. Deng, B.; Lan, L.; Houston, K.; Brady, P. V. Effects of clay minerals on Cr(VI) reduction by organic 290 compounds. Environ. Monit. Assess. 2003, 84 (1-2), 5-18; DOI 10.1023/A:1022890909779.

291 12. Puzon, G. J.; Petersen, J. N.; Roberts, A. G.; Kramer, D. M.; Xun, L. A bacterial flavin reductase 292 system reduces chromate to a soluble Cr(III)-NAD complex. Biochem. Biophys. Res. Commun. 2002, 293 294, 76-81;

294 13. Krumpolc, M.; Rocek, J. Chromium(V) oxidations of organic compounds. Inorg. Chem. 1985, 24 295 (4), 617-621;

296 14. Dunne, T. G. Spectra of Cr(III) complexes-An inorganic chemistry experiment. J. Chem. Educ. 297 1967, 44 (2), 101-103;

298 15. Meichtry, J. M.; Brusa, M.; Mailhot, G.; Grela, M. A.; Litter, M. I. Heterogeneous photocatalysis 299 of $\mathrm{Cr}(\mathrm{VI})$ in the presence of citric acid over $\mathrm{TiO} 2$ particles: relevance of $\mathrm{Cr}(\mathrm{V})$-citrate complexes. Appl. 300 Catal., B 2007, 71 (1-2), 101-107; DOI 10.1016/j.apcatb.2006.09.002.

301 16. Kabir-ud-Din; Hartani, K.; Khan, Z. One-step three-electron oxidation of tartaric and glyoxylic 302 acids by chromium(VI) in the absence and presence of manganese(II). Transition Met. Chem. 2002, 27 303 (6), 617-624; DOI 10.1023/A:1019819316240.

304 17. Mu, Y.; Jiang, X.; Ai, Z.; Jia, F.; Zhang, L. Mn2+ promoted Cr(VI) reduction with oxalic acid: The 305 indispensable role of In-situ generated Mn3+. J. Hazard. Mater. 2018, 343, 356-363; 306 10.1016/j.jhazmat.2017.10.008. 